\title{
General outline of the book
}

The book begins with a chapter by Pamela Samuelson, a legal scholar famous for her pioneering work on the copyright issues raised by new information technologies. In Chapter 1, she addresses what may be perhaps the most fundamental question regarding economics and copyright: just what role does economics have in copyright law and policy? Samuelson suggests that economics has not thus far been as influential in intellectual property law and policymaking as it has been in other areas of economic regulation, such as antitrust. She offers several possible explanations for this, including for example, lack of economic expertise on the part of the relevant policymakers, and 'the tight nexus between the copyright industry and the policymaking community'. Samuelson explains how economics does have an important and useful role to play in copyright law and policy - touching also on ways economics can be misused - and offers several examples and case studies.

The chapter by Samuelson, in addressing some of the institutional and methodological difficulties that contribute to a law/economics divide, serves to introduce the book as a whole. The primary focus of the book's succeeding sections is the application of economic tools and analysis to examine particular issues within copyright. They begin with considering the economics of copyright collectives.

In Chapter 2, Arthur Snow and Richard Watt offer a novel view of the benefits of copyright collectives in their capacity to pool the risks of their members. While it is well-known that collective administration of copyright can reduce transaction costs, the potential risk-sharing benefit of copyright collectives has not been previously considered. Using a formal analytical model, Snow and Watt show that when the final market value of each creator's work is uncertain, a copyright collective can improve the welfare of its risk-averse members by alleviating individual risks. Snow and Watt also point out that despite this potential risk-sharing benefit, the actual allocation rules employed by copyright collectives in fact preclude this benefit for their members.

In Chapter 3, Stan Liebowitz carefully examines the benefits and costs of certain proposals that have been put forth as alternative solutions to the problem of peer-to-peer music filesharing. Under these proposals, a copyright collective would be formed to administer a tax-and-subsidy system 
whereby the record industry's traditional revenue sources would be replaced (or supplemented) by revenue generated from taxation of ancillary products (e.g., CDs, ISP services, etc.). Such a system could either entirely replace the current copyright system or it could serve as a restitution mechanism to compensate copyright owners for losses induced by unauthorized copying. Some of the benefits of such a system might include, for example, decriminalization of widespread illegal behavior, enhanced incentives for the production of creative works, and increased consumption. Liebowitz argues, however, that the costs of such a system, including for example, those induced by tax distortions and a mispriced royalty rate, as well as the potential for 'gaming' the system, make such proposals (as his title indicates) 'a cure worse than the disease'.

Peer-to-peer music filesharing is also addressed by Anne Duchêne and Patrick Waelbroeck in Chapter 4. However, in contrast to Chapter 3's emphasis on proposals to resolve the problems induced by peer-to-peer music filesharing, Chapter 4 is premised on the idea that firms may benefit from peer-to-peer networks in their capacity to convey information to consumers about new music cheaply, as compared to the more costly traditional mechanisms (e.g., advertising and promotions). Duchêne and Waelbroeck's main thesis is that increasing copyright protection may have significantly disparate welfare consequences, depending upon whether information is conveyed to consumers via peer-to-peer networks ('demandpull') or via traditional mechanisms ('demand-push'). They develop a model from which they derive welfare implications of increasing copyright's criminal penalties under both demand-pull and demand-push mechanisms when firms can also employ their own additional technological protection against piracy (e.g., digital rights management). They find, among other things, that increasing criminal penalties benefits firms employing demand-push mechanisms and induces them to increase their level of technological protection, while the reverse is true for firms employing peer-to-peer networks. The effect of potential audience size on the firm's preferred information transmission mechanism is considered as well.

In Chapter 5, Timothy Brennan addresses the issue of fair use, the flexible doctrine employed by US law that allows behavior to occur - such as some copying in educational, private, and journalistic contexts - that would otherwise constitute prima facie copyright infringement. Brennan examines the fair use doctrine in light of the diversity of policy goals that have been proposed for its application. To this end, he develops a model from which he derives optimal fair use standards under several different policy objectives. Specifically, in addition to economic efficiency, he considers four possible alternate policy objectives: maximization of number of works supplied, aggregate consumer surplus, gross benefit, and numbers of 
uses. By deriving ordered rankings for the optimal levels of fair use under each of the above standards, Brennan shows how fair use might be adjusted 'to address the breadth of policy goals that might be considered'.

In Chapter 6, Christopher Yoo criticizes the standard economic analysis of copyright that typically assumes copyright turns creators into monopolists. Yoo argues that the well-known 'access-incentives' tradeoff is largely driven by the assumed monopolization of the market. If one instead considers the impact of copyright within a framework that allows for product differentiation and entry, the access-incentives tradeoff may be less significant. By increasing producer appropriability and profit, increased copyright protection can stimulate entry of competitors producing similar works, resulting in lower prices, increased product variety, and increased access. Yoo suggests that this approach also makes a broader set of policy instruments potentially available for use, but disentangling the effects of one from another can be quite complicated.

In Chapter 7, Giovanni Ramello argues that the 'standard' economic analysis of copyright is too narrowly focused on individual creation. In particular, economists have failed to consider the inherently social nature of knowledge production, which takes place in what Ramello calls the 'social creative commons'. While economists have recognized that copyright restricts access to output (i.e., to the copyrighted good), they have been insufficiently sensitive to the ways in which copyright also restricts access to inputs (i.e., to the creative commons and the production of knowledge). Ramello argues that restricting access to the creative commons and hence, to knowledge sharing, reduces the future productive capacity of the creative commons, a consequence which Ramello calls an 'opposite tragedy of the creative commons'. For these reasons, Ramello argues for a 'minimalist' rather than a 'maximalist' approach to copyright.

In Chapter 8, Alessandra Narciso and Paul Torremans examine the interaction and proper balance between copyright and competition (antitrust) law. Their analysis largely focuses on the German IMS Health case, a case that well illustrates the tension that exists between copyright and competition law. Narciso and Torremans' main thesis is that the application of competition law to cases in which copyright exists should factor in and avoid undermining the structural system originally put in place by copyright. So, for example, in antitrust cases involving copyright, it may be inappropriate to employ as precedent court decisions in non-copyright cases, at least without explicit recognition of the special structure intentionally put into place by copyright. Narciso and Torremans apply this notion to several other policy issues raised by the IMS Health case, with a focus on the essential facilities doctrine.

In Chapter 9, Scott Kieff and Troy Paredes provide a strong argument 
for applying, both at the judicial and legislative levels, 'a basics approach' to issues in dispute that arise at 'the periphery of intellectual property law'. Too often, they argue, such disputed matters are resolved in a piecemeal fashion by creating specialized approaches and unique doctrines. This approach, they argue, 'selectively emphasizes or alternatively ignores particular features of various legal disciplines in crafting specialized doctrines for IP'. In contrast, under their competing 'basics approach,' Kieff and Paredes propose that such matters would be best resolved by applying the basics of the relevant substantive law, such as intellectual property law, antitrust law, and property law. Although Kieff and Paredes focus on patent law, their analysis applies equally to copyright. For example, they argue that the anti-circumvention provisions of the Digital Millennium Copyright Act are inconsistent with the 'basics approach' since the transactions it regulates are better governed under existing contract law or the IP law of indirect infringement.

As this brief review of the contents of this volume shows, both economists and legal scholars are applying their analytical skills to a broad range of theoretical and applied areas in the economics of copyright. We hope that the volume will stimulate further research and debate in this important area. 
Lisa N. Takeyama, Wendy J. Gordon, and Ruth Towse - 9781781951224 Downloaded from PubFactory at $04 / 26 / 2023$ 11:48:42AM 